\title{
ISLAMIC BANKING MARKET DISCIPLINE IN INDONESIA
}

\author{
Joko Suliyono ${ }^{1}$ and Tastaftiyan Risfandy ${ }^{2}$ \\ ${ }^{1}$ Faculty of Economics and Business, Universitas Sebelas Maret, Indonesia, \\ joko.suliyono@student.uns.ac.id \\ ${ }^{2}$ Center for Fintech and Banking, Universitas Sebelas Maret, Indonesia, \\ tastaftiyan.risfandy@staff.uns.ac.id
}

\begin{abstract}
This paper examines the market discipline of Islamic banks, as manifested by the responses of depositors with regard to their deposits and profit-sharing ratio to the fundamentals of the banks in the case of Indonesia. We analyse the supply and demand function of deposits using panel data from 10 Islamic banks from 2010 Q1 to 2019 Q4. We empirically find that market discipline in Indonesian Islamic banks is relatively weak, and conjecture that this is for two reasons. First, religious depositors have driven the unusual behaviour of Islamic banks, as we find that they stay with the same bank, even if it has poor fundamental conditions. Second, the profit and loss sharing mechanism means that Islamic bank depositors do not have great flexibility in demanding a higher rate relevant to the risk they must bear. This is because depositors' actual return is set to be consistent with the actual profit obtained from the banks' lending activities. Our results lead to the call for policymakers to effectively monitor the fundamental conditions of Islamic banks and to collaborate with agencies and organisations that promote Islamic bank development in Indonesia.
\end{abstract}

Keywords: Market discipline, Deposits, Bank fundamentals, Islamic banks, Indonesia. JEL classification: G21; G28; Z12.

\author{
Article history: \\ Received : October 14, 2020 \\ Revised : March 18, 2021 \\ Accepted : : May 27, 2021 \\ Available online : August 31, 2021
}

https://doi.org/10.21098/jimf.v7i3.1376 


\section{INTRODUCTION}

\subsection{Background}

The Islamic banking system has attracted the attention of many parties, including researchers, customers, and policymakers. Islamic banking is well growing and developing in some countries such as Iran, Sudan, Bangladesh, Brunei, Kuwait, Malaysia, Qatar, Saudi Arabia, the United Arab Emirates, and Yemen. The relatively high Muslim population is one of the reasons why Islamic banks have grown significantly in these countries. Indonesia is a country of more than 207 million Muslims, or $87.2 \%$ of the total population, representing a great potential market share for the Islamic banking industry. In 2019, there were 14 fully-fledged Islamic banks, 20 Islamic windows (UUS), and 164 Islamic rural banks. In the last five years, Islamic banking assets have also grown significantly, from IDR 252 trillion in 2014 to IDR 499 trillion in 2019, or an increase of 98\% (Indonesian banking statistics, October 2019). All of this development suggests a bright future for Islamic banking in Indonesia.

Indonesia is one of the countries that has adopted a dual banking system; that is, conventional and Shariah banks operate simultaneously in one banking system. This type of system greatly affects depositors' behaviour, such as that related to the number of deposits they make into banks. The nature of deposits in Islamic banks is theoretically different from that of conventional banks. Islamic banks adhere to the principle of profit and loss sharing, meaning depositors cannot claim a fixed rate of return on their savings (Meslier, Risfandy, \& Tarazi, 2017). In a dual banking system, depositors' religious character plays a vital role in making decisions to move their funds from conventional to Islamic banks (Aysan, Disli, Duygun, \& Ozturk, 2016). Meslier et al. (2017) empirically show that conventional banks offer higher deposit rates when their market power is lower as a response to Islamic bank penetration. While conventional banks are influenced by the competitiveness of Islamic banks, the latter are only influenced by the level of competition within the Islamic bank environment itself.

Islamic banking applies a profit-sharing system that can function as an early warning system or a tool for monitoring banking performance. If the share of profit received by depositors shows an upward trend, it can be concluded that Islamic bank performance is good. Conversely, if the share is tending to decrease, Islamic banks may be experiencing poor lending performance. In this situation, depositors can decide whether to keep their funds in the same Islamic banks, transfer them to other Islamic banks, or even to conventional banks. Depositors can "punish" Islamic banks by asking for an increase in the level of profit-sharing, or withdraw all their funds from the banks (Martinez-Peria \& Schmukler, 2001).

Any choice made by depositors, whether to keep their funds in Islamic banks or transfer them, will impact banking performance (Aysan et al., 2016). On the one hand, on the Islamic bank side, if depositors are given a high share of the profit, they may still decide to stay with the bank. However, this policy is not without cost, as it will significantly increase the cost of funds. On the other hand, if Islamic banks do not change their interest policy, depositors will possibly withdraw their funds, leading to a fall in bank assets.

In this study, we examine the behaviour of Islamic bank deposits and their association with the banks' financial condition or bank fundamentals. More specifically, our purpose is to investigate whether Islamic bank deposits increase 
(or decrease) when there are better (or worse) fundamental bank condition. We also investigate whether the ex-post profit-sharing rate paid to depositors is higher (or lower) in banks with better (or worse) accounting performance. With this approach, it is possible to understand whether market discipline "works" in the Indonesian context; e.g., if poorly-performing Islamic banks increase their ex-post profit-sharing rate to retain existing depositors.

The paper fills the gaps related to market discipline in the Islamic banks context, which has been rarely explored in the literature. Previous studies have paid great attention to the conventional bank context (Bennett et al., 2015; Hadad et al., 2011; Hasan et al., 2013; Yan et al., 2014, amongst others), but only a few have focused on Islamic banks (Aysan et al., 2016; Aysan, Disli, Ozturk, \& Turhan, 2015; Meslier et al., 2017), even though such banks have specific characteristics that distinguish them from their conventional peers. This paper follows that of Hasan and Tandelilin (2012), who investigated Islamic vs. conventional bank deposits, observing stronger market discipline in the Islamic bank context. However, our approach is different, as we focus solely on Islamic banks, rather than comparing the two bank types. By considering only the Islamic bank side, our paper offers a more detailed investigation regarding the deposits of such banks, an approach that Narayan and Phan (2017) recommend that further Islamic banking research should focus on. The more in-depth investigation presented in this paper is based on both the supply and demand sides of deposits, using both the levels of deposits and the profit-sharing rate. To the best of our knowledge, this is the first paper in the field of Islamic banking to focus on the market discipline of Indonesian Islamic banks using demand and supply equations. This is because the nature of deposits follows the demand and supply equation, so it would be preferable if the existence of market discipline was also assessed from both sides. Previous research in the Indonesian context has been conducted by Nys, Tarazi, \& Trinugroho (2015), especially on conventional banks, but no studies have considered the issue from the Islamic bank perspective.

\subsection{Objective}

This paper enriches the studies in the field of market discipline by considering the Islamic bank angle. Shariah-based banks have been reported in previous empirical studies to display different behaviour from their conventional counterparts. Islamic bank deposits are regarded as crucial, as they are one of the most distinct aspects of Islamic banks that make them different from their conventional peers, e.g., the presence of profit and loss sharing mechanism. However, similar tp their conventional conterparts, Islamic depositors' responses to any change in bank fundamentals are an important sign of the existence of market discipline. Therefore, the objectives of this paper are to answer the following research questions:

1) Do Islamic banks' fundamental conditions affect the size of deposits in Islamic banks?

2) Do Islamic banks' fundamental conditions affect the rate of deposits in Islamic banks?

The existence of market discipline in Islamic banks could be established if a significant impact of bank fundamentals is found on both the size and rate of deposits. More specifically, a significant impact means that Islamic bank deposits 
increase (or decrease) when they have better (or worse) bank fundamental conditions and the ex-post profit-sharing rate paid to depositors is higher (or lower) in the banks with worse (or better) accounting performance.

The remainder of this paper is organised as follows. Section two presents the theoretical background, while Section three highlights the method used in the study. Section four explains the empirical results, and Section five concludes.

\section{LITERATURE REVIEW}

\subsection{Theoretical Background}

\subsubsection{Market Discipline}

Market discipline refers to a mechanism by which stakeholders react in response to changes in firms' conditions, in such a way that firm behaviour is kept in check. In the case of banks, this may be exemplified, for example, by depositors seeking higher rates of returns or withdrawing their deposits as ways of disciplining the banks and discouraging them from risky undertakings, or as responses to banks' worsening financial health (Cubillas, Fonseca, \& González, 2012; Martinez-Peria \& Schmukler, 2001). In market discipline, depositors are predicted to demand higher returns on their deposits or withdraw their funds in response to a decline in bank fundamentals (Aysan et al., 2016). When a bank's fundamentals deteriorate, depositors can discipline the bank by withdrawing uninsured deposits or asking for an increase in the risk premium (Maechler \& McDill, 2006). Market discipline has the potential to play an important role in promoting financial stability because it can encourage banks to increase capital adequacy and choose a safer asset structure (Hasan et al., 2013). It can also be a useful complement to bank regulators' health and safety surveillance (Bennett et al., 2015). Depositors do not differentiate between large and small banks, but some differences occur in market discipline between subsidiary foreign banks and domestic ones (Yan et al., 2014). Market discipline is more clearly felt in banks listed on the capital market than in those not listed, and in foreign banks compared to domestic banks (Hadad et al., 2011). Therefore, regulators should encourage more domestic banks to be listed on the capital market to increase market discipline.

\subsubsection{Bank Fundamentals}

In Indonesia, commercial banks' soundness is formally regulated by Peraturan Bank Indonesia No. 13/1/PBI/2011 (formal regulation from the Central Bank of Indonesia. This regulation highlights the rating system for commercial bank soundness using a component assessment called RGEC (Risk profile, Good corporate governance, Earnings, and Capital). The risk profile is an assessment of the inherent risk and quality of risk management implementation in bank operations, including asset quality and liquidity. The asset quality component is used to assess the condition of banking assets, including anticipation of the risk of default from financing activities. The liquidity component is used to assess a bank's ability to maintain a stable liquidity level, while good corporate governance is used to assess the internal managerial ability of a bank in running its business. The earnings component is used to measure the ability of banks to generate corporate profits, and finally capital is used to assess the adequacy level of bank capital. 
In this paper, we measure the RGEC component using measurements retrieved from previous empirical research. According to Alqahtani et al. (2016), asset quality can be measured using the NPF (Non-Performing Financing) ratio; liquidity by the FDR (Financing to Deposit Ratio); governance/management by the cost to income ratio or inefficiency ratio; earnings by the ROA (Return On Asset) ratio; and capital can be measured using the CAR (Capital Adequacy Ratio). The risk profile, GCG, earnings and capital factors can be used to investigate whether depositors choose Islamic banks because they are more stable, have better capital, or are more liquid, efficient, and profitable than conventional banks (Naqvi, Rizvi, Uqaili, \& Chaudhry, 2018).

\subsubsection{Islamic Bank Deposits}

Islamic banking is a financial institution that applies Shariah principles in all its activities. The difference between Islamic banks and conventional ones lies in the former's main pillars, namely the prohibition of interest or usury (Aysan, Disli, Duygun, \& Ozturk, 2018). Products issued by Islamic banking do not involve usury (interest), gharar (uncertainty), maysir (gambling) or any non-halal activities (being prohibited). Before depositors put their funds into a bank, they will first consider many issues, such as the bank's financial condition, its investment level, and physical building. Service quality, namely compliance, assurance, reliability, empathy, and responsiveness, also greatly affect customer satisfaction (Janahi \& Al Mubarak, 2017).

To examine Islamic bank deposits, and whether they react to changes in fundamental bank conditions, the actual profit sharing rate of each individual depositor should be used. However, data on these are relatively scarce and held confidentially by each bank. Therefore, following some previous studies (Hadad et al., 2011; Meslier et al., 2017; Nys et al., 2015), in this paper we use the implicit deposit rate and the aggregate amount of deposits.

\subsubsection{Deposit Insurance in Indonesia}

The deposit insurance that applies in a country can affect the level of market discipline (Martinez-Peria \& Schmukler, 2001). In Indonesia, the institution that guarantees depositors' funds is the Indonesia Deposit Insurance Corporation/ Lembaga Penjamin Simpanan (IDIC/LPS), which guarantees depositors' funds up to a maximum nominal value of Rp. 2 billion per named depositor in each bank. Banks whose depositors are guaranteed by the LPS are in the category of commercial and rural banks, and can be either conventional or Islamic banks. With the LPS guarantee, depositors will feel safe and protected from bad risks in banks where they deposit funds, and from market risks, business risks, and other risks.

Some of the policies implemented by the LPS to improve market discipline include: (1) limiting the amount of guaranteed funds; (2) limiting the type of guaranteed fund; (3) limiting the parties related to the guaranteed fund; and (4) establishing the distribution priority of liquidation. Consequently, bank customers who have funds that exceed the guaranteed limit will face risks in the case of bank default. Therefore, they do not have any other choice but to monitor the bank's performance in order to ensure their money is safe. 
From the LPS perspective, the parties expected to exercise market discipline are large customers and creditors. Small customers do not really have access to information or the ability to assess banks' conditions and performance, so they are more sensitive to issues regarding these. As a result, small customers are more prone to panic and bank runs when they hear about negative bank issues. In the deposit insurance system, the risks faced by small customers are transferred to the LPS so that the risk of bank runs can be anticipated.

\subsubsection{Macroeconomic Conditions}

Banking market discipline, both Shariah and conventional, is influenced by the macroeconomic conditions of a country. Some previous empirical research that has examined the determinants of banking performance has focused on internal factors. In contrast, external ones such as gross domestic product, interest rates, and financial sector development can also affect banking performance. Hadad et al. (2011) also used macroeconomic variables in the form of gross domestic product, inflation, and the rupiah/USD exchange rate to examine market discipline. In this article, we focus on both GDP and inflation as the macroeconomic variables. Inflation can encourage economic growth if it is at a relatively low level below $10 \%$ per year and can motivate business actors to improve their business. Inflation pushes up prices, so can provide benefits for them. An increase in inflation will encourage the growth of customer deposits (Maechler \& McDill, 2006).

\subsection{Previous Studies}

Previous research on banking market discipline has been widely conducted. Martinez-Peria and Schmukler (2001) show that depositors in Argentina, Chile, and Mexico penalise banks for risky behaviour by withdrawing their deposits and demanding higher interest rates. Maechler and McDill (2006) concluded that uninsured depositors were sensitive to bank fundamentals, including changes in interest rates. Focusing on banks' deposit growth and interest rate spreads, Yan et al. (2014) showed that market discipline was found to work in Australian banks.

Hadad et al. (2011), who investigated the presence of market discipline in the Indonesian context, used several measures of bank risks to proxy for bank fundamentals: (1) the ratio of loan loss reserves to gross loans to proxy for credit risk; (2) the ratio of liquid assets to total assets to proxy for liquidity risk; (3) the z-score to proxy for insolvency risk; and (4) the log of total assets to proxy for bank size. In a similar vein, Nys et al. (2015) used demand and supply analysis to investigate the existence of market discipline in Indonesia associated with politically-connected banks. They used the same bank fundamentals variable as Hadad et al. (2011), but also used non-performing loans (NPLs) and return on assets (ROA) to proxy for overall bank risk and profitability respectively.

Some studies have reported that market discipline also works in the Islamic bank context, particularly because of the competitive situation between Islamic banks and their conventional peers. Meslier et al. (2017) show that conventional banks are sensitive to Islamic bank deposit rates, while Islamic banks are only influenced by their peers, and mostly in Muslim majority countries. Conventional bank depositors are relatively less sensitive to changes in interest rates than Islamic 
ones because only the largest group of depositors is significantly responsive to interest rate shocks. All depositors in Islamic banks, except those in the smallest group of depositors, are very sensitive to interest rate changes in the market (Aysan et al., 2018).

\section{METHODOLOGY}

\subsection{Data and Sample}

Our bank-level data (CAR, NPF, INEFF, ROA and FDR) were retrieved from the Indonesia Financial Services Authority (OJK), while figures for GDP and inflation were extracted from the Indonesia Statistical Bureau. We used a sample of ten Islamic banks with full observations (balanced panel) from 2010Q1 to 2019Q4: PT Bank Muamalat Indonesia Tbk, PT Bank Syariah Mandiri, PT Bank BRI Syariah, PT Bank BCA Syariah, PT Bank Maybank Syariah Indonesia, PT Bank Mega Syariah, PT Bank Panin Syariah Tbk, PT Bank Syariah Bukopin, PT Bank BTPN Syariah and PT Bank Victoria Syariah.

\subsection{Model Development}

In order to investigate the existence of market discipline in Islamic banking in Indonesia, we constructed the following supply and demand regression models, which is consistent with previous studies (Meslier et al., 2017; Nys et al., 2015):

$$
\begin{aligned}
D E P_{i, t}= & \alpha+\beta_{1} \text { RATE }_{i, t}+\beta_{2} C A R_{i, t-1}+\beta_{3} N P F_{i, t-1}+\beta_{4} I_{N E F F_{i, t-1}}+\beta_{5} \text { ROA }_{i, t-1}+ \\
& \beta_{6} F D R_{i, t-1}+\beta_{7} \text { SIZE }_{i, t-1}+\beta_{8} G D P_{t}+\beta_{9} \text { Inflation }_{t}+\varepsilon \\
\text { RATE }_{i, t}= & \alpha+\beta_{1} \text { CAR }_{i, t-1}+\beta_{2} N P F_{i, t-1}+\beta_{3} \text { INEFF }_{i, t-1}+\beta_{4} R O A_{i, t-1}+ \\
& \beta_{5} F D R_{i, t-1}+\beta_{6} \text { SIZE }_{i, t-1}+\beta_{7} \text { GDP }_{t}+\beta_{8} \text { Inflation }_{t}+\varepsilon
\end{aligned}
$$

The dependent variable are the size of customer deposits (DEP) and the rate of profit sharing (RATE), that have been widely used previously in the study of market discipline. It can be said that market discipline exists when (1) bank fundamentals have a positive association with the size of deposits (DEP), and (2) they have a negative relation with the implicit deposit rate (RET). In the first case, this is because depositors will withdraw their money from the banks, and hence the size of deposits will decrease when the banks' fundamentals deteriorate. It is therefore defined as a supply equation, because bank fundamentals will have impacts on the supply of deposits to banks. In the second case, a negative association is expected because when banks perform poorly, depositors will ask for a higher rate as compensation for the risk they have to take. The second equation is defined as a demand function since it is related to the depositors' rate demand. Our assumption of market discipline is in line withprevious studies. MartinezPeria and Schmukler (2001) show that bank fundamentals significantly affect the size of deposits and deposit rates, while Hadad et al. (2011), using an Indonesian sample, highlight that depositors' interest rates are inversely proportional to the blanket guarantee and CAR schemes. 
Table 1.

Variable Definitions

\begin{tabular}{|c|c|}
\hline Variable & Explanation/Definition \\
\hline DEP & $\begin{array}{l}\text { Total deposit size in Islamic banks (in logarithm form), defined as unrestricted savings or } \\
\text { investment funds entrusted by non-bank third party customers to Islamic banks and/or } \\
\text { Shariah business units, based on a wadiah or mudharabah contract in the form of demand } \\
\text { deposits, savings, deposits and or other equivalent forms. In this paper, we use the total } \\
\text { deposit size. }\end{array}$ \\
\hline RATE & $\begin{array}{l}\text { The profit-sharing rate in Islamic banks, defined as a cooperation agreement between } \\
\text { customers as owners of capital (shahibul maal) and banks as capital managers (mudharib). } \\
\text { In this research, we use the implicit deposit rate, calculated as the ratio of total profit- } \\
\text { sharing expense to total deposits. }\end{array}$ \\
\hline CAR & $\begin{array}{l}\text { The capital adequacy ratio, calculated by dividing total equity by total assets, which } \\
\text { indicates banks' ability to provide their own funds to overcome the possible risk of losses. }\end{array}$ \\
\hline NPF & $\begin{array}{l}\text { The ratio of non-performing financing to total financing made of banks to indicate } \\
\text { Islamic banks' credit/financing risk. }\end{array}$ \\
\hline INEFF & $\begin{array}{l}\text { A ratio that shows the inefficiency of banks in conducting their business activities, } \\
\text { calculated by dividing total operating costs by total income. }\end{array}$ \\
\hline ROA & $\begin{array}{l}\text { Return on assets, calculated by dividing net income by total assets. ROA measures the } \\
\text { ability of banks to generate profits from all the assets owned. }\end{array}$ \\
\hline FDR & $\begin{array}{l}\text { The financing to deposit ratio, which measures the ability of banking liquidity to meet } \\
\text { obligations to third-party funds by relying on financing that has been distributed to the } \\
\text { public. }\end{array}$ \\
\hline SIZE & $\begin{array}{l}\text { The log of total assets, as an indicator to assess the size of Islamic banking in terms of } \\
\text { total assets owned. }\end{array}$ \\
\hline GDP & $\begin{array}{l}\text { Growth of Gross Domestic Product (GDP) as an indicator of a country's economy. GDP } \\
\text { measures the total value of products produced by all the population and local and } \\
\text { foreign companies. }\end{array}$ \\
\hline INFL & $\begin{array}{l}\text { National inflation, as one of the macroeconomic components that affects customer } \\
\text { deposits. }\end{array}$ \\
\hline
\end{tabular}

The independent variable in this study is bank fundamentals, proxied by five ratios as part of RGEC (Risk Profile, Good corporate governance, Earnings, and Capital): CAR (capital-assets ratio), NPF (non-performing financing), INEFF (inefficiency ratio), ROA (return-on-assets), and FDR (financing-to-deposits ratio). Martinez-Peria and Schmukler (2001) found that an increase in the CAR ratio encouraged the growth of depositors' funds. Yan et al. (2014) also concluded that an increase in CAR encourages growth in customer deposits. Martinez-Peria and Schmukler (2001) and Nys et al. (2015) indicate that the NPF significantly affects depositor funds, while Naqvi et al. (2018) and Alqahtani et al. (2016) used the INEFF (cost-to-income ratio) as one of the fundamental components of CAMEL banks to measure the growth of assets of Islamic and conventional banks. MartinezPeria and Schmukler (2001) and Nys et al. (2015) show that a high ROA bank will attract more customer funds. Alqahtani et al. (2016) used the FDR as one of the fundamental components of banks to measure Islamic and conventional banks' significant asset growth. 
The control variables in the study are GDP and inflation. Maechler and McDill (2006) and Nys et al. (2015) show that GDP has a positive correlation with depositors' fund growth. A higher GDP will encourage the growth of customer deposits. Maechler and McDill (2006) and Nys et al. (2015) also used the inflation variable as one of the macroeconomic components affecting customer deposits. An increase in inflation will encourage the growth of customer deposits. Definitions of all the variables used in the study are given in Table 1.

\subsection{Method}

Equations (1) and (2) were estimated separately using fixed effects. This technique was chosen because we used a panel data structure (with both cross-sectional and time-series dimensions), and previous studies have suggested that our supplydemand model are static (Hadad et al., 2011; Meslier et al., 2017; Nys et al., 2015). The best way to deal with a static panel data structure is by using fixed and random effects techniques (Wooldridge, 2016). We also tested which model, fixed effects or random effects, was more appropriate, using Hausman tests structure (Gujarati \& Porter, 2009; Wooldridge, 2016). The Breusch Pagan LM test and Chow test were also used to provide further evidence that the OLS method was not appropriate for our panel data structure (Gujarati \& Porter, 2009; Wooldridge, 2016).

\section{RESULTS AND ANALYSIS}

\subsection{Descriptive Statistics}

Table 2 presents the descriptive statistics, which contain the number of observations, the average value, the standard deviation, the minimum value, and the maximum value of each variable. The value of the capital adequacy variable (CAR) shows an average of $20.45 \%$, which indicates Islamic banks' ability to cover losses on assets using their own capital. This CAR value is high compared to the minimum capital adequacy limit set by the OJK, which is $8-11 \%$, meaning that Islamic banking capital is very strong. The average NPF value is around $2 \%$, which is still within the limit set by Bank Indonesia of 5\%. This indicates that the financing channeled by Islamic banking to the public is prudent. It also means that the risk management of Islamic banking is very good. The value of the INEFF ratio, which refers to the ratio of operating expenses to operating income, is spread in the range of $87.12 \%$ to $155.84 \%$.

The profitability ratio (ROA) ranges from an average of $1.00 \%$, which indicates that on average Islamic banking in Indonesia is only able to generate profits of $1.00 \%$ from total assets owned. This low level of ROA indicates that Islamic banks have not been able to generate sufficient profits from their available capital. In addition, the value of the FDR variable, which shows the composition of the financing provided compared to the amount of capital owned, ranges from a minimum value of $73.12 \%$ to $149.82 \%$. The distribution side of financing is quite good, with few idle funds kept; some of which are even higher than $100 \%$. Islamic banking is quite aggressive in distributing funds to the public in the form of financing. The last bank-level variable (SIZE) shows the size of Islamic banking in terms of total assets and has an average of 15.84(logarithm form). The GDP 
Table 2.

Descriptive Statistics

\begin{tabular}{lccccc}
\hline \multicolumn{1}{c}{ Variable } & Obs & Mean & Std. Dev. & Min & Max \\
\hline DEP & 368 & 15.3469 & 2.1937 & 3.9703 & 18.3068 \\
RATE & 368 & 0.0384 & 0.0235 & 0.0089 & 0.0991 \\
CAR & 368 & 0.2040 & 0.0661 & 0.1064 & 0.2939 \\
NPF & 368 & 0.0214 & 0.0152 & 0.0045 & 0.0497 \\
INEFF & 368 & 1.1332 & 0.1586 & 0.8712 & 1.5584 \\
ROA & 368 & 0.0099 & 0.0246 & -0.1077 & 0.1004 \\
FDR & 368 & 0.9741 & 0.2112 & 0.7312 & 1.4982 \\
SIZE & 368 & 15.8489 & 1.5366 & 12.5474 & 18.9365 \\
GDP & 368 & 5.4538 & 0.6060 & 4.7400 & 6.8100 \\
INFL & 368 & 0.4125 & 0.4774 & -0.3500 & 2.4600 \\
\hline
\end{tabular}

Note: Please see Table 1 for a description of each variable

and INFLATION variables have an average of $5.4 \%$ and $0.4 \%$, which indicates that Indonesia's economic strength in our sample period is relatively good.Table 3 contains the correlation matrix of all the independent variables used in the study. It can be observed that there is no high correlation between the variables, hence multicollinearity should not be a major issue. To reaffirm this, we also computed the VIF (Variance Inflation Factor), which is provided in the last column of Table 3. The VIF value of each independent variable is less than 10, so it can be concluded that the model is free from multicollinearity problems.

Table 3.

Correlation Matrix and Variance Inflation Factors (VIF)

\begin{tabular}{lccccccccc}
\hline & CAR & NPF & INEFF & ROA & FDR & SIZE & GDP & INFL & VIF \\
\hline CAR & 1.000 & & & & & & & & 2.02 \\
NPF & -0.395 & 1.000 & & & & & & & 1.51 \\
INEFF & 0.187 & -0.404 & 1.000 & & & & & & 2.68 \\
ROA & 0.103 & -0.333 & 0.673 & 1.000 & & & & & 1.96 \\
FDR & 0.338 & -0.166 & 0.387 & 0.142 & 1.000 & & & & 1.40 \\
SIZE & -0.564 & 0.148 & -0.031 & -0.005 & -0.273 & 1.000 & & & 1.87 \\
GDP & 0.003 & -0.284 & 0.343 & 0.170 & 0.053 & -0.274 & 1.000 & & 1.49 \\
INFL & -0.017 & 0.055 & 0.036 & -0.019 & -0.039 & -0.015 & 0.051 & 1.000 & 1.02 \\
\hline
\end{tabular}

Note: Please see Table 1 for a description of each variable

\subsection{Specification Tests}

We conducted three specification tests in order to determine which estimators were the most appropriate for our model: The Breusch-Pagan Lagrangian Multiplier (LM) test, the Hausman test, and the Chow test. The results of the tests are shown in Table 4 . First, the results of the LM test are significant, with a 
p-value of $<0.01$. This rejects the null hypothesis that OLS residuals do not have individual-specific errors, suggesting that panel data with the random effects technique are more appropriate. Second, we used the Hausman test to determine which panel data analysis, fixed-effects or random-effects, was more appropriate for use in the model. Table 4 shows a significant result $(p<0.01)$, implying that the null hypothesis of the Hausman test (that the error term is not correlated with the explanatory variable) is rejected. This result suggests that random-effects is inconsistent, and that fixed-effects is the most appropriate method. Third, we also tested whether pooled OLS was appropriate in our model by using the Chow test. While the null hypothesis of this test is that the regression coefficient does not vary between individuals, our significant result $(p<0.01)$ rejects this. Therefore, fixedeffects are the best estimators for use in the study. The results are similar for both Equations (1) and (2).

Table 4.

Specification Tests

\begin{tabular}{lcc}
\hline & $\begin{array}{c}\text { DEP } \\
\text { Equation (1) }\end{array}$ & $\begin{array}{c}\text { RATE } \\
\text { Equation (2) }\end{array}$ \\
\hline Chow Test (p-value) & 0.000 & 0.000 \\
Breusch Pagan LM Test (p-value) & 0.000 & 0.000 \\
Hausman Test (p-value) & 0.000 & 0.000 \\
\hline
\end{tabular}

\subsection{Regression}

The regression results are shown in Table 5. Column (1) shows the results for the supply equation (equation (1)), whereas column (2) refers to the demand equation (equation (2)). In the supply equation, the results are mixed and therefore it cannot be concluded whether the market discipline mechanism strongly exists in Islamic banks. It is the only the capital ratio (CAR) and bank size (SIZE) that have signs in line with our prediction. The capital ratio proxied by CAR has a significant and positive effect on deposits, meaning that if banks have higher capital, more customers will be motivated to put their funds into them. Larger banks can also become a magnet for customers to deposit their money. These results are consistent with those of previous studies (Martinez-Peria \& Schmukler, 2001; Yan et al., 2014), highlighting that an increase in CAR encourages the growth of deposit supply.

For the four other variables (NPF, INEFF, ROA, and FDR), we found contradictory results, which might also suggest that the market discipline in Islamic banks in Indonesia is relatively weak. We found a positive sign for nonperforming financing (NPF) and inefficiency (INEFF), which means that lower non-performing financing and lower inefficiency are related to lower depositor funds. We also found positive signs for profitability (ROA) and liquidity (FDR), suggesting that banks' supply of deposits will increase when they have lower profitability and liquidity. This finding contradicts most previous studies. More efficient and more profitable banks will usually be able to reduce operating expenses and increase operating income (Alqahtani et al., 2016; Naqvi et al., 2018). This result shows that market discipline does not work well in the Indonesian context. 
Table 5.

Regression Results

\begin{tabular}{|c|c|c|c|c|}
\hline & $\begin{array}{l}\text { DEP } \\
\text { (1) }\end{array}$ & Prediction & $\begin{array}{l}\text { RATE } \\
\text { (2) }\end{array}$ & Prediction \\
\hline \multirow[t]{2}{*}{ L.RATE } & $-15.75^{* * *}$ & + & & \\
\hline & $(-5.03)$ & & & \\
\hline \multirow[t]{2}{*}{ L.CAR } & $3.459^{* *}$ & + & $0.0422^{*}$ & - \\
\hline & (2.52) & & (1.66) & \\
\hline \multirow[t]{2}{*}{ L.NPF } & $8.074^{*}$ & - & -0.0802 & + \\
\hline & $(1.84)$ & & $(-0.98)$ & \\
\hline \multirow[t]{2}{*}{ L.INEFF } & $1.540^{* * *}$ & - & -0.00545 & + \\
\hline & (2.84) & & $(-0.54)$ & \\
\hline \multirow[t]{2}{*}{ L.ROA } & $-13.97^{* * *}$ & + & $0.0894^{*}$ & - \\
\hline & $(-4.81)$ & & (1.65) & \\
\hline \multirow[t]{2}{*}{ L.FDR } & $-1.406^{* * *}$ & + & 0.0109 & - \\
\hline & $(-3.42)$ & & (1.47) & \\
\hline \multirow[t]{2}{*}{ L.SIZE } & $1.505^{* * *}$ & + & $-0.00760^{* * *}$ & - \\
\hline & (14.49) & & $(-4.12)$ & \\
\hline \multirow[t]{2}{*}{ GDP } & -0.117 & $\mathrm{n} / \mathrm{a}$ & $-0.0331^{* * *}$ & $\mathrm{n} / \mathrm{a}$ \\
\hline & $(-0.41)$ & & $(-6.61)$ & \\
\hline \multirow[t]{2}{*}{ INFL } & 0.0480 & $\mathrm{n} / \mathrm{a}$ & 0.00113 & $\mathrm{n} / \mathrm{a}$ \\
\hline & $(0.30)$ & & $(0.38)$ & \\
\hline \multirow[t]{2}{*}{ Constant } & $-8.077^{* * *}$ & $\mathrm{n} / \mathrm{a}$ & $0.333^{* * *}$ & $\mathrm{n} / \mathrm{a}$ \\
\hline & $(-3.20)$ & & (7.67) & \\
\hline Observations & 368 & 368 & 368 & 368 \\
\hline Number of banks & 10 & 10 & 10 & 10 \\
\hline R-squared & 0.622 & 0.622 & 0.556 & 0.556 \\
\hline
\end{tabular}

Notes: Please see Table 1 for variable explanations. Robust standard errors are in parentheses. ${ }^{* * *},{ }^{* *}$, and ${ }^{*}$ denotes significance at levels of $1 \%, 5 \%$, and $10 \%$ respectively.

We now turn to the results from the demand equation (Equation (2), column (2)). It was hypothesised that market discipline does exist when customers require a higher rate relative to the risk that they have to bear. In the case of Islamic banks, depositors will ask for a higher return (profit-sharing rate) when they put their money into a riskier bank. Column (2) shows that the size of the banks (SIZE), the capital ratio (CAR), and profitability (ROA) have a positive association with the rate of profit sharing. Smaller banks tend to offer higher rates to make their depositors stay with them, which is in line with the market discipline theory. For ROA and CAR, our results strengthen the findings of the supply equation. Less profitable banks (low ROA) and less risky banks (low CAR) tend to provide lower rates for their customers, which should be the other way round according to market discipline theory. However, when we consider this in the context of 
the profit-sharing mechanism, this becomes clearer because returns provided to depositors should not be based on the market rate or depositors' demands, but instead on the actual return that Islamic banks can obtain (Farook, Hassan, \& Clinch, 2012). While our results do not correspond to the market discipline theory, they confirm the profit-sharing mechanism in Islamic banks.

\subsection{Analysis of the Empirical Findings and Discussion}

It can be concluded that the results discussed above are mixed and it cannot be said that market discipline in the Islamic bank market is strong. In the supply function, some variables, such as capital ratio and size, show that market discipline does exist in Islamic banks, as they show a positive impact on the size of deposits. However, for the remaining variables, the results contradict the theory. In the demand function, we found that only size was negatively associated with the rate of deposits, which is consistent with the theory. However, we also found that profitability and the capital ratio positively affected the deposit rate, meaning that higher profitability and stability are associated with the higher rate.

There could be two reasons why some contradictory results appeared in the research, leading to the conclusion of a weak market discipline mechanism in Islamic banks. First, it should be noted that Islamic banks are established mainly to serve Muslims, because Muslims might view that interest is prohibited in Islam. Although in practice not all Muslims use Islamic banks (the reason being outside the focus of this paper), some do stay with their bank regardless of its condition. These are usually called "religious" Muslims and will remain with the banks because they are the only choice they have. The different behaviour of Islamic banks could be attributed to the religiosity of the customers they have; several previous studies have also highlighted this issue (Al-Shboul, Maghyereh, Hassan, \& Molyneux, 2020; Saiti, Wahab, \& Ahmad, 2017; Duqi, Jaafar, \& Warsame, 2019; Meslier et al., 2017; Meslier, Risfandy, \& Tarazi, 2020; Risfandy, Tarazi, \& Trinugroho, 2020; Risfandy, Trinarningsih, Harmadi, \& Trinugroho, 2019; I. Trinugroho et al., 2017; Irwan Trinugroho, Risfandy, \& Ariefianto, 2018).

Second, especially regarding the demand function, we observe that profitability and stability have a positive association with the deposit rate, which indeed contradicts market discipline theory. However, we also note that Islamic banks operate based on profit and loss sharing mechanisms. One of the implications of this system is that Islamic bank depositors will obtain returns corresponding to those that the bank obtains from lending. If Islamic banks can generate high profits, their depositors will also obtain a high return. In contrast, in the case of economic slowdown, or when Islamic banks perform poorly, their depositors cannot complain if they receive low returns or none at all. Therefore, our results actually strengthen the profit-sharing mechanism in Islamic banks that has also been underlined in previous papers (Farook et al., 2012; Farook, Hassan, \& Clinch, 2014; Meslier et al., 2017). 


\section{CONCLUSION AND RECOMMENDATIONS}

\subsection{Conclusion}

This article has investigated the existence of market discipline in Islamic banks in the Indonesian context. Our overall findings suggest that it is weak. The evidence for this could be based on two factors. First, Indonesian Islamic banks have religious depositors, who will remain with the banks in any fundamental conditions that they are experiencing. Second, the market discipline theory might be irrelevant in Islamic banks, since they operate through a profit-sharing mechanism. In this system, depositors theoretically cannot demand a higher rate of return because Islamic bank returns will always be associated with the actual business returns from their lending activities.

\subsection{Recommendations}

This research provides some significant policy recommendations. Policymakers should understand that Islamic bank deposits are not purely driven by the fundamental condition (e.g., profit or loss) of Islamic banks, but also the religiosity of the customers. Therefore, regulators should collaborate with all of the independent agencies (e.g., Muslim organisations, and Islamic bank forums and associations) and the government institutions which support the development of Islamic banks (e.g., in Indonesia: KNEKS - Komite Nasional Ekonomi dan Keuangan Syariah) in disseminating and promoting the benefits of Islamic banks. The regulator should also monitor the fundamental condition of Islamic banks because they are part of the national financial system and any instability could affect the stability of the whole country.

For further research, we make the following recommendation. A singlecountry study would still be interesting if the prospective authors could obtain explicit (non-implicit) rates and non-aggregate data on deposits. However, if such data are difficult to obtain, it might be better if the sample is expanded to all countries applying a dual banking system, not only a single one such as Indonesia.

\section{REFERENCES}

Al-Shboul, M., Maghyereh, A., Hassan, A., \& Molyneux, P. (2020). Political risk and bank stability in the Middle East and North Africa region. Pacific Basin Finance Journal, 60(June 2019), 101291. https://doi.org/10.1016/j.pacfin.2020.101291.

Alqahtani, F., Mayes, D. G., \& Brown, K. (2016). Economic turmoil and Islamic banking: Evidence from the Gulf Cooperation Council. Pacific Basin Finance Journal, 39(January), 44-56. https://doi.org/10.1016/j.pacfin.2016.05.017.

Aysan, A. F., Disli, M., Duygun, M., \& Ozturk, H. (2016). Islamic banks, deposit insurance reform, and market discipline: Evidence from a natural framework. Journal of Financial Services Research, 51(2), 257-282. https://doi.org/10.1007/ s10693-016-0248-z.

Aysan, A. F., Disli, M., Duygun, M., \& Ozturk, H. (2018). Religiosity versus rationality: Depositor behavior in Islamic and conventional banks. Journal of Comparative Economics, 46(1), 1-19. https://doi.org/10.1016/j.jce.2017.03.001. 
Aysan, A. F., Disli, M., Ozturk, H., \& Turhan, I. M. (2015). Are Islamic banks subject to depositor discipline? The Singapore Economic Review, 60(01), 1550007. https:// doi.org/10.1142/S0217590815500071.

Bennett, R. L., Hwa, V., \& Kwast, M. L. (2015). Market discipline by bank creditors during the 2008-2010 crisis. Journal of Financial Stability, 20, 51-69. https://doi. org/10.1016/j.jfs.2015.06.003.

Cubillas, E., Fonseca, A. R., \& González, F. (2012). Banking crises and market discipline: International evidence. Journal of Banking and Finance, 36(8), 22852298. https://doi.org/10.1016/j.jbankfin.2012.04.011.

Duqi, A., Jaafar, A., \& Warsame, M. H. (2019). Payout policy and ownership structure: The case of Islamic and conventional banks. The British Accounting Review, 52(1), 100826. https://doi.org/10.1016/j.bar.2019.03.001.

Farook, S., Hassan, M. K., \& Clinch, G. (2012). Profit distribution management by Islamic banks: An empirical investigation. The Quarterly Review of Economics and Finance, 52(3), 333-347. https://doi.org/10.1016/j.qref.2012.04.007.

Farook, S., Hassan, M. K., \& Clinch, G. (2014). Islamic bank incentives and discretionary loan loss provisions. Pacific-Basin Finance Journal, 28, 152-174. https://doi.org/10.1016/j.pacfin.2013.12.006.

Gujarati, D. N., \& Porter, D. C. (2009). Basic econometrics. New York: McGraw Hill Irwin.

Hadad, M. D., Agusman, A., Monroe, G. S., Gasbarro, D., \& Zumwalt, J. K. (2011). Market discipline, financial crisis and regulatory changes: Evidence from Indonesian banks. Journal of Banking and Finance, 35(6), 1552-1562. https://doi. org/10.1016/j.jbankfin.2010.11.003.

Hasan, I., Jackowicz, K., Kowalewski, O., \& Kozłowski, Ł. (2013). Market discipline during crisis: Evidence from bank depositors in transition countries. Journal of Banking and Finance, 37(12), 5436-5451.

Hasan, \& Tandelilin, E. (2012). Banking market discipline in Indonesia. Journal of Indonesian Economy and Business, 27(2), 159-173.

Janahi, M. A., \& Al Mubarak, M. M. S. (2017). The impact of customer service quality on customer satisfaction in Islamic banking. Journal of Islamic Marketing, 8(4), 595-604. https://doi.org/10.1108/JIMA-07-2015-0049.

Maechler, A. M., \& McDill, K. M. (2006). Dynamic depositor discipline in US banks. Journal of Banking and Finance, 30(7), 1871-1898.

Martinez-Peria, M. S., \& Schmukler, S. L. (2001). Do depositors punish bank for bad behavior? The Journal of Finance, 56(3), 1029-1051.

Meslier, C., Risfandy, T., \& Tarazi, A. (2017). Dual market competition and deposit rate setting in Islamic and conventional banks. Economic Modelling, 63(July), 318-333. https://doi.org/http://dx.doi.org/10.1016/j.econmod.2017.02.013.

Meslier, C., Risfandy, T., \& Tarazi, A. (2020). Islamic banks' equity financing, Shariah supervisory board, and banking environments. Pacific-Basin Finance Journal, 62, 101354. https://doi.org/10.1016/j.pacfin.2020.101354.

Naqvi, B., Rizvi, S. K. A., Uqaili, H. A., \& Chaudhry, S. M. (2018). What enables Islamic banks to contribute in global financial reintermediation? Pacific Basin Finance Journal, 52(October 2017), 5-25. 
Narayan, P. K., \& Phan, D. (2017). A survey of Islamic banking and finance literature: Issues, challenges and future directions. Pacific-Basin Finance Journal, (February 2017), 1-13. https://doi.org/10.1016/j.pacfin.2017.06.006.

Nys, E., Tarazi, A., \& Trinugroho, I. (2015). Political connections, bank deposits, and formal deposit insurance. Journal of Financial Stability, 19(January), 83-104. https://doi.org/10.1016/j.jfs.2015.01.004.

Risfandy, T., Tarazi, A., \& Trinugroho, I. (2020). Competition in dual markets: Implications for banking system stability. Global Finance Journal, (December 2019), 100579. https://doi.org/10.1016/j.gfj.2020.100579.

Risfandy, T., Trinarningsih, W., Harmadi, H., \& Trinugroho, I. (2019). Islamic Banks' market power, state-owned banks, and Ramadan: Evidence from Indonesia. The Singapore Economic Review, 64(02), 423-440. https://doi.org/ https://doi.org/10.1142/S0217590817500229.

Saiti, B., Wahab, H. A., \& Ahmad K. (2017). Contracts, structures, and computation mechanisms of Islamic bank retail financing products: A critical assessment. In N. Alam \& S. A. R. Rizvi (Eds.), Islamic banking; Growth, stability and inclusion (pp. 81-125). Cham, Switzerland: Palgrave Macmillan. https://doi.org/DOI 10.1007/978-3-319-45910-3.

Trinugroho, I., Risfandy, T., Ariefianto, M. D., Prabowo, M. A., Purnomo, H., \& Purwaningsih, Y. (2017). Does religiosity matter for Islamic banks' performance? Evidence from Indonesia. International Journal of Economics and Management, 11(2), 419-435.

Trinugroho, Irwan, Risfandy, T., \& Ariefianto, M. D. (2018). Competition, diversification, and bank margins: Evidence from Indonesian Islamic rural banks. Borsa Istanbul Review, 18(4), 349-358.

Wooldridge, J. M. (2016). Introductory econometrics: A modern approach. Boston, MA: Cengage Learning.

Yan, X., Skully, M., Avram, K., \& Vu, T. (2014). Market discipline and deposit guarantee: Evidence from Australian banks. International Review of Finance, 14(3), 431-457. https://doi.org/10.1111/irfi.12028. 